\title{
ANNOUNCEMENTS
}

\section{PUFENDORF PRIZE}

The Institute of International Law announces an essay competition on the following subject: 'The Historic Roots and Contemporary Foundations of Peremptory Rules (Jus Cogens) in the Theory and Practice of International Law'.

The competition, which carries a prize of SFr. 10,000 will be conducted in accordance with the Regulations applicable to the J.B. Scott prizes. These Regulations are reprinted in the Yearbook of the Institute of International Law, Vol. 61 (1986) Part II, pp 359-367.

The essays submitted for the Pufendorf Prize must conform to the conditions set forth in the above-named Regulations. They must be communicated, not later than 31 December 1994, to the following address:

M. Nicolas Valticos

22, Avenue William-Favre

CH-1207 Genève (Switzerland)

\section{SYMPOSIUM ON INTERNATIONAL AND ENVIRONMENTAL PROB- LEMS; TRANSBOUNDARY MOVEMENT OF HAZARDOUS WASTES}

The University of Utrecht's URIOS (Utrecht International Law Study Association) will hold the above-mentioned symposium on 7 November 1990. Among those speaking will be E. Nijpels (the former Dutch Minister for the Environment), representatives from the Dutch Ministry of the Environment, the EC, UNEP, Grüne-Liga (DDR), and members from the business community.

The symposium will take place at the Academy Building, Domplein 29, Utrecht, the Netherlands and will commence at $9.00 \mathrm{am}$. Attendance will cost Dfl. 30 (Dfl. 20 for students).

For further information contact:

URIOS

Janskerkhof 3

3512 BK Utrecht

The Netherlands

tel.: 030-393042 